Sonja Brlečić Valčić

University of Zadar

Department of Economics

23000 Zadar, Croatia

sbrlecicv@unizd.hr
Marko Valčić

University of Zadar

Maritime Department

23000 Zadar, Croatia

mvalcic@unizd.hr
JEL: C45, E32, E44, E47, E60, F45, G21, G28

Original scientific article

https://doi.org/10.51680/ev.34.1.3

Received: March 27, 2020

Revision received: January 8, 2021

Accepted for publishing: February 10, 2021

\title{
USING ANFIS IN JOINT DYNAMICS OF MONETIZATION, FINANCIAL DEVELOPMENT, PUBLIC DEBT AND UNEMPLOYMENT ANALYSIS
}

\begin{abstract}
Purpose: The modern concepts of contemplating joint dynamics of monetary policy effects on economic growth and its indicators require an indirect approach based on empirical research of mainly financial infrastructure, competitiveness of the financial markets and current economic conditions. Meanwhile, the problems of unemployment and the structure of employment within these concepts are most frequently linked with the polarization of the labor market and two important factors, that is, the effects of growth on unemployment and the fact that technological changes affect the changes in salary ranges.

Methodology: By using the Adaptive Neuro-Fuzzy Inference System (ANFIS) and the set of data from 1995 to 2016, this paper analyzes these issues through a prism of established balances between the labor and financial markets, i.e., the monetization of economy (M1/GDP), financial development (Loans/GDP) and the share of gross government debt in GDP (government gross debt/GDP).

Results: The proposed model suggests that the rate of unemployment is conditioned by the financial cycle and monetary policy (M1/GDP, Loans/GDP), as well as the business cycle and fiscal policy (gross d/BDP) and that a controlled and properly directed level of monetization of the economy (M1/BDP) and financial development measured as Loans/GDP can be "sufficient" for economic growth.

Conclusion: Waiting in the "monetary union lobby", i.e., waiting for the ERM II exchange mechanism can last longer than the set deadlines, leading to the need for Croatian economic policy to optimize monetary and fiscal policy measures in order to increase economic growth and reduce unemployment.
\end{abstract}

Keywords: Monetization of economy, financial development, structural problems of unemployment, ANFIS

\section{Introduction}

The collection of effective policies and factors implemented by institutions in authority with the purpose of acceleration and effective intermediation of the financial system can be seen as the financial development of a country. Although economists have different views on the relationships between financial development and economic growth, and consequently on the relationships among specific components preceding economic growth, the mere fact that the relationship has been extensively observed for several decades indicates that it exists and that it is imperative to continue observing the intensity 
of its existence as well as the elements and conditions that cause it. The nature of the relationship stems from the fact that a well-functioning financial system facilitates the diversification of risks and effective allocation of capital, and that the financial market development promotes the mobilization of savings and their allocation towards high-efficiency projects (Kutan et al., 2017).

This paper is based on previous research (Samodol \& Brlečić Valčić, 2018), in which the authors observed the spillover effects among the variables M1 (as narrowest monetary aggregate, which includes cash in circulation and overnight deposits in domestic and foreign currency), Gross debt, Loans and GDP and concluded that:

a) an increase in real M1 balance can serve as the basic value in less financially developed economies;

b) the spillover effects of M1/GDP to Loans/ GDP indicate that price setting on a wider level, through the interest amounts on deposits and loans in a specific development stage, should represent a mechanism through which financial sector development can promote economic development;

c) the spillover effects of Loans/GDP to Gross debt/GDP emphasize the necessity to design financial policies in accordance with the priorities of the industrial and economic policy, and

d) the existing level of economic earnings, substantially developed financial sector with appropriate regulations, available possibilities of financing and refinancing public debt as well as available statistical data provide solid grounds to Croatian policy makers for a different approach to managing and creating measures that will lead to a decrease in the unemployment rate.

Therefore, the research aimed at seeking a natural unemployment rate based on empirical data (1995 - 2016) showed that the average ratio M1/ GDP was $15 \%$, Loans/GDP 55\%, gross debt/GDP $48 \%$, with the average unemployment rate of $13 \%$. Furthermore, the analysis showed that a high unemployment rate (12\%) is present during economic growth (2003 - 2008 with average GDP growth rate of $4.3 \%$ ), but also that a high unemployment rate
(14\%) is present during economic decline (2009 2014 with average GDP decline rate of $2 \%$ ).

These results also indicate the need for a deeper analysis of the structure of unemployment, and highlight the problems of the polarization of the labor market in a contemporary context. This mainly refers to the occupations that were relatively intensive in routine job activities, i.e., tasks within specific work positions that have become cheaper and simpler to computerize in the last decades. These spheres cause differential changes in the structure of local production through (Autor \& Dorn, 2013):

- greater adoption of information technology;

- greater reallocation of low skill workers from routine task-intensive occupations into service occupations (i.e., polarization of employment);

- two-directional increase (in both employment and salaries) at both ends of the occupational skill distribution (i.e., wage polarization); and

- larger net inflows of both high and low skill labor attracted by these demand shifts.

The specified issues of the polarization of the labor market should be observed through a prism of established balances between the labor and monetary markets, that is the monetization of economy (M1/ GDP), financial development (Loans/GDP) and the share of government debt in GDP (government gross debt/GDP).

Based on the above, a research question arises: Can a model for an effective analysis of the balance between the labor market and the availability of financial resources, i.e., monetization of the economy, based on variables M1/GDP, Loans/GDP and government gross debt/GDP be created and what are the results of analyses conducted by this model?

In seeking to identify joint dynamics of the observed variables, we used the Adaptive Neuro-Fuzzy Inference System (ANFIS) as a universal approximator in modeling non-linear functions of several variables (Jang, 1993).

\section{Overview of previous research}

Measuring the effects of monetary policy on economic growth and its indicators requires an indirect approach based on empirical research of mainly financial infrastructure, competitiveness of the 
financial markets and current economic conditions (Avci \& Yucel, 2017).

The modern approach to observing financial infrastructure within the context of joint effects of monetization of economy and financial development on economic development requires taking into account the observations of the latest research related to:

a) financial development,

b) size and effects of the financial system,

c) effects of financial activity development,

d) presence and significance of banks in financial infrastructure,

e) transmission channels and

f) government interventions in the availability of financial funds.

The effect of financial development on economic growth and development can be observed from four aspects (Nyasha \& Odhiambo, 2017). One view is that financial development is important and leads toward economic growth. Another view is that the development of the real sector leads to the development of the financial sector even when there is economic growth, i.e., the financial sector follows economic development. The third aspect is the "feedback hypothesis" presupposing a bi-directional causality between financial development and economic growth. It gives the same importance to the financial development and to the development of the real economic sector. The last aspect, the "neutral hypothesis" indicates that the role of financial development in economic growth is often unfounded or overestimated, i.e., that there is no causality between the two macroeconomic variables.

Nyasha and Odhiambo (2017) find that the causality of the financial and economic development cannot be observed through linear dependence. In any case, the financial development should assist in reducing the negative effects of the exchange rate volatility on capital inflow, which leads to a conclusion that a developed financial system is a significant channel through which less developed countries can improve capital inflow in the long term. This is especially related to mechanization of remittances that financial sector development should ensure (Jehan \& Hamid, 2017).
If we observe the significance of the size and effect of the financial system on economic growth, we see that different variables representing the financial sector provide different results in this area. Likewise, the analyses show that an oversized volume of the financial sector, especially excess lending or an oversized share of unpaid loans negatively affect the growth of GDP (Prochniak \& Wasiak, 2017).

The effect of financial activity development on economic growth varies in relation to the period in which it is observed and the development level of a specific country. Likewise, although private loans prevent long-term growth, they increase short-term growth, except in countries with low employment rate (Hou \& Cheng, 2017). In relation to the first mentioned priority, the level of the presence and importance of banks in the financial infrastructure is a precondition of economic growth only if a large part of funds is directed toward financing companies and investment, and not crediting households and private property (Capolupo, 2017).

The financial system mainly affects the real sector through the following transmission channels: balance-sheet channel, interest rate channel, bank capital channel and the uncertainty channel (Ankargren et al., 2017).

The competitiveness of financial markets can be viewed from the aspect of:

- financial sector development and

- financial system regulation with strong domestic foundations.

The mechanism through which financial sector development can foster economic growth depends on price differences in specific stages of financial development. On these bases, it is possible to develop a range of financial markets that will gradually finetune financial prices, including the development of products with better liquidity and risk management characteristics, which increase the contribution of the financial sector to economic efficiency (Lynch, 1996).

The path to satisfactory financial development begins with basic monetization and not with early and active introduction of potentially unstable markets for complex financial instruments. Financial structures should be based on political stability, good public finances and stable monetary engagement. With these elements in place, banks can function 
with the institutional support needed to grow and thrive. An increase in real M1 balances can serve as a basic store of value in less financially developed economies, allowing agents to overcome project indivisibilities and encouraging capital accumulation (Rousseau \& D’Onofrio, 2013).

Despite the fact that the emergence of foreign banks in the markets of developing countries had a positive impact on corporate environment indicators (Hartwell, 2018), a long-term growth strategy of a country should be articulated by good operation and appropriate regulation of the financial system with strong domestic foundations. This would increase the net benefits of financial development for domestic and foreign investors (Desbordes \& Wei, 2017). However, the effect of local financial development on financial integration is conditional on the level of economic development, indicating that greater financial development conditioned by similar levels of economic development should precede closer financial integration (Cheng \& Daway, 2018).

In order to measure the effects of monetary policy on economic growth with regard to current economic conditions, it is necessary to observe the relationship and connection between GDP and monetary variables, monetary policy effectiveness, adoption of target inflation, the effect of financial friction, unfavorable macroeconomic environment, labor market polarization in the modern context, etc.

The effectiveness of the monetary policy depends on the extent to which the selected interest rate affects all other financial prices, including the entire structure of interest rates, credit rates, exchange rates and asset prices. Competition in the banking sector (as well as the liquidity and profitability of the sector), a high level of dependence on another currency, exchange rate flexibility, inflation and value structure all have a positive impact on interest rate pass-through, while the regulatory quality, GDP growth, monetary growth, industrial growth and capital inflow have a negative impact (Avci \& Yucel, 2017). However, there are opposing views, i.e., some researchers concluded that variables such as inflation and money supply do not significantly affect real production (Ellison \& Sargent, 2015), or that the dependence needs to be observed in relation to the type of economy and the country, taking into account the phase of the economy i.e., whether it is in decline or growing (Simionescu et al., 2017).
The research of these relationships shows that crediting the private sector significantly stimulates economic growth in the long term regardless of the presence or absence of institutional quality. Likewise, institutional quality increases lending to the private sector and money supply, but also economic growth through the development of financial markets (Kutan et al., 2017).

Financial friction is a divide between the return received by financial capital providers, i.e., the consumers, and the cost of capital paid by companies and consumers who use the capital (Hall, 2011). Financial friction emphasizes the reduction of investment in plants, equipment and inventory, which stems from an expanding gap between received earnings by savings holders and efficient spending of funds for companies and households dependent on lending. The gap (financial friction) widens when financial institutions earn higher spreads than those that emerge from their funding expenses and their interest charges (Hall, 2013).

In low levels of financial development, there is a strong effect of redistribution, and the fall of financial friction increases productivity shocks (Pinheiro et al., 2017).

Unfavorable macroeconomic environment defined by the deviation from an acceptable limit in the parameters of Excessive Imbalance Procedure - a set of indicators for alarm mechanism monitoring, leads to an intensity of crisis phenomena. Latest research (Pera, 2016) shows that there is a significant correlation in the parameters of current account balance $(\mathrm{CAB})$, net international investment position (NIIP), export market shares (EMS), nominal unit labor costs (NULC), real house prices (RHP), private sector debt (PSD), government debt (GD) and unemployment rate (UR).

The similarities in the structure of imports within each sector within the members of the monetary union can decrease the frequency of idiosyncratic import shocks. More specifically, the homogenization process of sector import structure is an important factor in real convergence, as well as a potential determinant of the level of similarity of the cycle. Research shows that since the emergence of the European Monetary Union, the cycles of eurozone member states have been synchronizing with the total eurozone cycle, with the exception of Greece.

The significant part of the trade basket in less developed countries is made up of basic goods and 
services. This means that the relative movement of commodity prices can have serious consequences for economic growth. Moreover, the movement of commodity prices has an asymmetrical impact on the economic activity of a country, i.e., in periods of decline, commodity prices support the rise of the GDP for commodity importers but decrease the growth of commodity exporters (Harvey et al., 2017).

The link between analyzed policies and economic growth should be established through a satisfactory level of employment. Economic policy affects employment primarily through monetary and fiscal policies, which with their instruments affect aggregate supply and demand for goods and services. Some research shows that Croatian monetary policy has had a limited effect on reducing unemployment (Benazić \& Rami, 2016).

Croatia's experience suggests that high level of euroization is difficult to reduce despite the country's long history of macroeconomic and exchange rate stability and credible monetary policy, which included regulatory measures for discouraging banking business in foreign currencies (Dumičić et al., 2017).

Furthermore, unemployment is directly affected by growth through the obsolescence rate, and indirectly through the effects of development incentives for companies. The sign of total impact of growth on unemployment depends on its source (a higher growth can be a result of an increase in the size and frequency of innovations or accumulation of human capital through education). Endogenization of the growth process (through the endogenization of research activities, for example, that set the amount and frequency of innovations or by introducing learning by working with positive external effects throughout the sector) introduces new interactions between growth and unemployment. It also creates a possibility of multiple equilibria and encourages the role of government intervention (Aghion \& Howitt, 1994).

In addition, Croatian labor market faces other challenges, from fragmentation and inappropriate structure to unfavorable dynamics, and behaving as a fractionally integrated process (Bošnjak et al., 2017). The inefficiency of unemployment reduction measures in Croatia can be linked to the public debt and government instability.
An insight into the drivers of public debt is the basis for formulating both fiscal policy and public debt management policy that can help to reduce government borrowing costs and improve public finance sustainability (Andabaka et al., 2017). It can be closely related to the results of the analysis of the government's economic policy, which has shown that unstable governments, which often depend on a number of smaller parliamentary actors, find it difficult to succeed in fiscal consolidation. All governments were inclined to use frequent changes to tax legislation as a fiscal policy instrument (DeskarŠkrbić \& Raos, 2017).

\section{Data set and methodology}

With the purpose of modeling the effects of selected indicators M1/GDP, Loans/GDP and Gross debt/GDP on Unemployment, we used the Adaptive Neuro-Fuzzy Inference System (ANFIS) on the set of data for the period from 1995 to 2016. It should be noted that ANFIS as a methodology has not been used for similar analyses so far. It was used for optimization of production inventory problem (Abdel-Aleem et al., 2017), prediction of consumer price index (Ambukege et al., 2017), modeling production uncertainties (Azizi et al., 2015), modeling product returns in a closed-loop supply chain under uncertainties (Efendigil, 2014) and other problems related mainly to the optimization of production. Moreover, as a universal approximator, ANFIS offers a range of applications such as modeling nonlinear functions of multiple variables, identifying nonlinear components of on-line control systems, prediction of chaotic time series, etc. (Jang, 1993).

Using an input-output dataset, ANFIS delivers a Fuzzy Inference System (FIS), whereby the membership functions parameters are adapted by a backpropagation learning algorithm or combined with the method of least squares (hybrid learning method). Such a setup allows the FIS system to learn from training data. In comparison with pure fuzzy inference systems, which are usually based on IF-THEN rules defined by the users (experts), ANFIS automatically performs the induction of these rules directly from observations. Although input membership functions can be of any kind within ANFIS structure, the output membership functions can be only constant or linear because ANFIS only operates on Sugeno-type systems (Sugeno, 1985). 
For the purpose of this paper, the data were collected by the authors using publicly available sources of the Croatian National Bank, shown in Table 1. All the data were used for input-output mapping, i.e., for training only. The procedure of model validation was not performed for several reasons. Firstly, this model was not created for prediction purposes but solely for identification of model nonlinearities in order to discuss the relationship of selected input and target variables that is more reliable, particularly in comparison with multivariate linear regression models. In this context, the modeling approach used by ANFIS is similar to many system identification techniques, with exceptional capabilities of capturing nonlinearities, but without significant overfitting issues. This is best presented with smooth surfaces of input-output mapping shown in Figure 1. The obtained smooth surfaces suggest the absence of noise in data, which is very favorable for ANFIS modeling and indicates the quality of used data.

Furthermore, the amount of available data is relatively small, so validation approaches that are typically used in machine learning like $k$-fold or leave-one-out approach do not have much sense considering the aim and purpose of this data-driven model. In addition, the number of observations is smaller than the number of modifiable parameters and any additional splitting of this set to training and testing subsets would reduce the model performance. However, it should be pointed out that in this form, the model cannot be used as a multivariate time series model for prediction, which is a significant drawback of the model in general, but not for the purpose of this paper.

Table 1 Data for modeling the effects of indicators M1/GDP, Loans/GDP and Gross debt/GDP on Unemployment

\begin{tabular}{|c|c|c|c|c|}
\hline \multirow{2}{*}{ Year } & \multicolumn{3}{|c|}{ Inputs } & \multirow{2}{*}{$\begin{array}{c}\text { Target } \\
\text { Unemployment }\end{array}$} \\
\hline & M1/GDP & Loans/GDP & Gross debt/GDP & \\
\hline 1995 & 8.23 & 32.70 & 19.00 & 10.00 \\
\hline 1996 & 10.53 & 31.20 & 28.43 & 10.00 \\
\hline 1997 & 11.07 & 39.26 & 27.30 & 9.90 \\
\hline 1998 & 9.81 & 43.31 & 26.24 & 11.40 \\
\hline 1999 & 8.47 & 33.76 & 29.56 & 13.60 \\
\hline 2000 & 10.19 & 34.18 & 35.82 & 16.10 \\
\hline 2001 & 12.32 & 38.64 & 36.51 & 15.80 \\
\hline 2002 & 14.80 & 46.12 & 36.83 & 14.80 \\
\hline 2003 & 14.81 & 48.32 & 38.10 & 14.30 \\
\hline 2004 & 13.99 & 50.97 & 40.38 & 13.80 \\
\hline 2005 & 14.36 & 54.74 & 40.70 & 12.70 \\
\hline 2006 & 16.47 & 61.92 & 38.30 & 11.20 \\
\hline 2007 & 17.96 & 65.03 & 37.70 & 9.90 \\
\hline 2008 & 15.88 & 67.39 & 39.60 & 8.50 \\
\hline 2009 & 14.26 & 70.33 & 49.00 & 9.20 \\
\hline 2010 & 14.63 & 73.57 & 58.20 & 11.60 \\
\hline 2011 & 15.48 & 75.77 & 65.00 & 13.70 \\
\hline 2012 & 15.70 & 71.53 & 70.60 & 15.90 \\
\hline 2013 & 17.57 & 70.65 & 81.70 & 17.30 \\
\hline 2014 & 19.16 & 69.30 & 85.80 & 17.30 \\
\hline 2015 & 20.84 & 65.65 & 85.40 & 16.20 \\
\hline 2016 & 23.94 & 61.60 & 82.90 & 13.10 \\
\hline
\end{tabular}

Source: Authors using Croatian National Bank Bulletins 1996-2017 (https://www.hnb.hr) 
As mentioned previously, the ANFIS model was created with three input variables $\left(x_{1}=\mathrm{M} 1 /\right.$ GDP, $x_{2}=$ Loans/GDP, $x_{3}=$ Gross debt/GDP) and one target variable ( $y=$ Unemployment). This was performed with Fuzzy Logic Toolbox as a part of MathWorks MATLAB R2019b software package.

Grid partitioning method was used for generation of associated fuzzy inference system (FIS). Thus, for three associated inputs, ANFIS will generate a number of IF-THEN rules of the form

$$
\begin{aligned}
& \operatorname{IF}\left(x_{1} \text { is } A_{1}\right) \operatorname{AND}\left(x_{2} \text { is } A_{2}\right) \text { AND }\left(x_{3} \text { is } A_{3}\right) \\
& \operatorname{THEN}\left(y_{i}=p_{i} x_{1}+q_{i} x_{2}+r_{i} x_{3}+s_{i}\right)
\end{aligned}
$$

where $A_{1}, A_{2}$ and $A_{3}$ are linguistic variables from associated fuzzy sets $\{\mathrm{VL}, \mathrm{L}, \mathrm{M}, \mathrm{H}, \mathrm{VH}\}$ in which VL stands for "Very Low", L is "Low", M is "Medium", $\mathrm{H}$ is "High" and VH is "Very High". Each of these linguistic variables is defined in terms of so-called membership functions (MF) that define how each point in the input space is mapped to a membership value. For the purpose of this research, a degree of membership is defined with a bell-shaped function of the form

$$
\mu_{A_{i}}=\frac{1}{1+\left|\left(x-c_{i}\right) / a_{i}\right|^{2 b_{i}}}
$$

where $\left(a, b, c_{i}\right)$ are so-called assumed parameters that need to be adjusted during ANFIS training phase. Similarly, FIS output $y_{i}$ in (1) is presented as a linear function of input variables with four socalled consequential parameters $\left(p_{i}, q_{i}, r_{i} s_{i}\right)$ that also have to be adjusted during the training phase. In this research, the type of the output membership function was chosen as constant.

It can be seen from (1) that ANFIS generates IFTHEN rules with AND operator, although they can be generated with OR operator as well, if needed. However, the latter option is very rare in practice. Therefore, in order to cover all possible combinations for 3 input variables $\left(x_{1}, x_{2}, x_{3}\right)$ and 5 linguistic variables (VL, L, M, H, VH), ANFIS will generate a total of $5^{3}=125$ IF-THEN rules of the form (1).

In terms of parameters that have to be adjusted, one can notice that for 3 input variables, each de- fined with 5 bell-shaped membership functions, where each membership function contains 3 parameters, a total number of these nonlinear parameters $\left(a_{i}, b_{i}, c_{i}\right)$ is $3.5 \cdot 3=45$. On the other hand, considering that we have 125 fuzzy rules with 125 constant outputs $y_{i}$, we could have an additional 125 linear quadruples of parameters $\left(p_{i}, q_{i}, r_{i}, s_{i}\right)$ if the output membership function is linear, or an additional 125 parameters $\left(s_{i}\right)$ if the output membership function is constant. In this research, the latter option was chosen in order to decrease the total number of adjustable parameters, which is equal to $45+125=170$. It is very important to note that one should be careful and distinguish between FIS outputs $y_{i}$ from output (target) values listed in Table 1.

The goal of the ANFIS training is minimization of deviations between observed and estimated target values, which is performed by adjusting both the assumed parameters $\left(a, b, c_{i}\right)$ in the first layer and consequential parameters $\left(p_{i}, q_{i}, r_{i}, s_{i}\right)$ in the second layer of the ANFIS structure. This tuning of parameters, similar to system identification, can be performed using a backpropagation algorithm alone, which is very often used in neural network training, or in combination with least squares estimation. The latter approach, also known as hybrid optimization for ANFIS training, was used in this research. More details on ANFIS training can be found in Jang (1993) or Valčić et al. (2011).

Initial conditions of this hybrid optimization for previously defined problem were set very strictly, i.e., to zero tolerance error or 100 epochs whichever value the algorithm reaches first. However, with data provided in Table 1 and with previously described ANFIS structure, algorithm converged to minimal training RMSE (Root Mean Square Error) equal to 0.00006 , which was achieved after 13 epochs. Converging of training error was relatively fast and stable.

\section{Results and discussion}

The input-output mapping of the created ANFIS, as the multivariate nonlinear model, can be visually presented as a range of combinations in different relationships between the Unemployment as a dependent variable and any other two independent variables, as shown in Figure 1 below. 
Figure 1 The input-output mapping of the created ANFIS

Relationship M1/GDP, Loans/GDP and unemployment

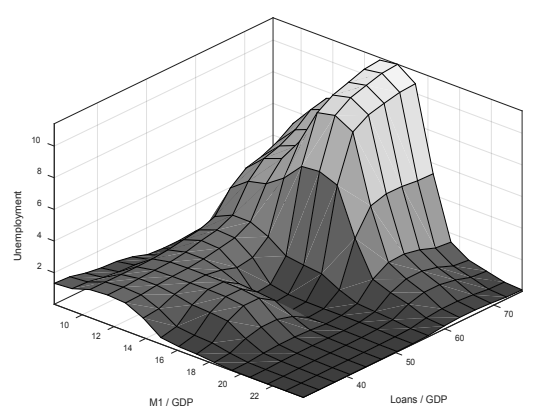

Relationship M1/GDP, Gross Debt/GDP and unemployment

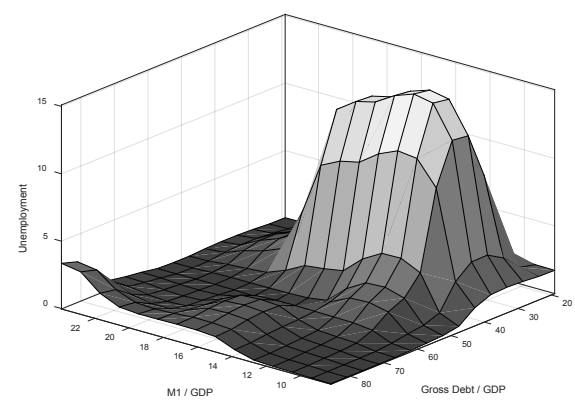

Gross Debt/GDP, Loans/GDP and unemployment

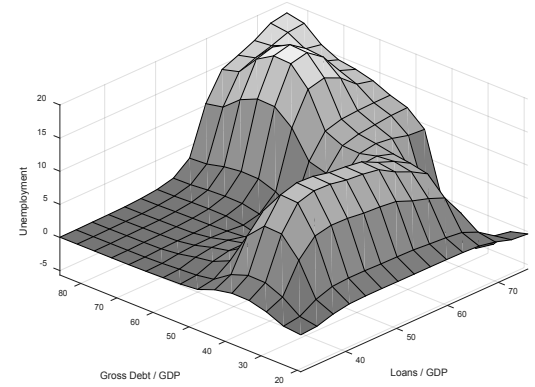

Source: Authors

As previously emphasized, this ANFIS model was not created for prediction purposes, but rather for the analysis of the input-output relationship. In other words, for this research it is not so important to calculate output value (Unemployment) for any given triplet (M1/GDP, Loans/GDP, Gross debt/GDP), but to examine all sufficiently accurate triplets of previously defined discrete values (M1/ GDP, Loans/GDP, Gross debt/GDP) for any given value of Unemployment variable. Once the system identification has been performed, the created ANFIS model can be used for this combinatorial analysis, which was coded by the authors also using MathWorks MATLAB R2019b software. In this way, we can obtain a clearer picture of the combinations of variables M1/GDP, Loans/GDP and Gross debt/GDP, which generate some given Unemployment value that is of particular interest. This ap- proach also provides the necessary data for comprehensive discussion.

With respect to the research problem defined in the introductory part of the paper, the main constraint related to independent variables was the fact that the Republic of Croatia needs to limit the share of public debt in GDP to $60 \%$ in order to meet the Maastricht convergence criteria. Furthermore, before entering the monetary union, the country needs to participate in the so-called Exchange Rate Mechanism ERM II with the established criteria of the exchange rate variability (that might affect the level of monetization of the economy). The published political decision by the Croatian government and the central bank from 2017 shows that the plan is to join ERM II in 2020, while according to the same plan the introduction of euro would take place in 2023. Considering these facts as reality, the model took into account primarily the un- 
employment rate and the share of debt in GDP, and then we sought to identify the objectively possible level of monetization (M1/GDP) and financial development (Loans/GDP).
The selected rates, observed in the range from desirable ( $5 \%$ and $7 \%$ unemployment) to those realistically expected in the period leading to the introduction of EUR $(8.5 \%$ and $10 \%)$ with a low level of deviation from the desirable share of debt in GDP, are shown in Table 2.

Table 2 Ratio M1/GDP and Loans/GDP considering the set criteria for Gross debt/GDP and Unemployment rate

\begin{tabular}{|c|c|c|c|}
\hline M1/GDP & Loans/GDP & Gross debt/GDP & Unemployment \\
\hline 12.8 & 61.3 & 59.1 & 5.00 \\
\hline 10.8 & 74.8 & 59.6 & 5.00 \\
\hline 13.3 & 72.3 & 62.1 & 5.00 \\
\hline 18.3 & 62.3 & 60.1 & 7.00 \\
\hline 14.3 & 59.3 & 60.6 & 7.00 \\
\hline 13.8 & 67.8 & 62.6 & 8.50 \\
\hline 13.8 & 70.3 & 59.1 & 8.50 \\
\hline 14.3 & 60.3 & 60.6 & 9.00 \\
\hline 16.8 & 59.8 & 59.6 & 9.00 \\
\hline 16.8 & 59.3 & 62.1 & 10.00 \\
\hline
\end{tabular}

Source: Authors

Detailed results of the analysis can be found in Appendix (Tables 3, 4, 5, 6 and 7).

The analyses of the data shows that the level of M1/ GDP ranged from 8.23 to 23.94 in the $1995-2016$ period, while in 2017 it exceeded 27. The Loans/ GDP values for the observed period ranged from 31.2 to 75.77 . Taking these values into consideration, it is possible to classify low, medium and high levels of the observed variables.

The targeted unemployment rate of $5 \%$ in the set criterion with approximately $60 \%$ Gross debt/GDP requires a low level of M1/GDP and a relatively high level of Loans/GDP, whereas the unemployment rate of $7 \%$ can be achieved with medium or high levels of M1/GDP and Loans/GDP. An unemployment rate of $8.5 \%, 9 \%$ and $10 \%$ requires a medium level of M1/GDP and a high level of Loans/GDP.

More specifically, Table 2 shows that the targeted direction of unemployment in the first period would require a level of M1/GDP of 16.8 , i.e., the current level of 27.4 indicates excessive and unused liquidity of banks. A similar level of M1/GDP of 16.47 was recorded in 2006, a year in which the share of loans to businesses was higher than those to households, leading to a logical conclusion that this is a model to follow, i.e., a recommendation of good practice. After that, the level should be lowered to 14, with a gradual decrease in loans to businesses and placement of funds toward households.

The desired unemployment rate of $5 \%$ requires a level of M1/GDP 1013, which was already recorded in the 2000 - 2001 period. The required level of Loans/GDP should increase slightly in the beginning from the current 57.5 to $59-60$ (which was recorded in the 2006 - 2007 period). Lower unemployment rates require a further increase of the ratio to levels of $70-74$. To find solutions for the desired levels of the mentioned ratios, it is necessary to observe the existing financial infrastructure through financial development, size and impact of the financial system, the effect of financial activity development and the presence and significance of banks in the financial infrastructure.

The turning point in the time trajectory of the Croatian financial system development was in 2003/2004 when the nominal amount of assets of the total financial sector exceeded the size of GDP, so that by the end of 2017 the financial sector assets were $61 \%$ higher than GDP. 
In addition, the share of banks' assets in the total financial sector assets at the end of 2017 was almost $70 \%$, and from 2002 to the financial crisis of 2008 , the share of banks' assets ranged between 75 and $90 \%$, making the entire financial sector bank oriented.

In 2006, the banks' assets surpassed the amount of GDP, leading to 2017 when they were $12.5 \%$ higher than the GDP. In the period of recession (which lasted from 2009 - 2014 in our region), the share of banks' assets in GDP was over 25\%, which is understandable considering the cumulative drop of GDP to $12 \%$ in the same period.

It is noteworthy that in the structure of banks' assets, loans to businesses and households never dropped below $50 \%$, and in the period of growth from 2002 to 2008 , the share of loans to the private sector reached $65 \%$ in the total assets. However, after 2002 loans granted to households often exceeded those granted to businesses, which eventually set the structure of domestic economy that was oriented more toward consumption and import than production and export.

All this led to a business and financial cycle, which clearly shows the connection between loans and GDP, while the statistical relationship between the movement of annual GDP levels and loans to businesses is missing. Moreover, after 2009 and the onset of recession to the end of 2017, the net drop in GDP was $-3.7 \%$, while the deleveraging of the business sector led to a net drop in loans of $12 \%$ and a net drop in loans to citizens of $8 \%$.

Considering the orientation toward banks instead of potentially unstable markets for complex financial instruments, a conclusion can be made that in the observed period satisfactory financial development that begins with basic monetization was achieved.

However, the period in which it was necessary to change the orientation from banks to more complex markets coincided, unfortunately, with the period of intensive crisis that lasted far too long due to the lack of political stability, solid public finances and stable monetary arrangement. These three building blocks, along with institutional support, are required by banks and markets to help the economy grow and thrive.

The competitiveness of the financial market dominated by banks deteriorated further, because the monetary authority imposed additional regulatory demands in the midst of crisis, leading to a regulatory paradox and making the regulation of banks procyclical. With the implementation of Basel III from 2014 to 2019 , diminished lending activity of banks and the lack of instrument of open market policy to the end of 2015, the regulatory conditions and expenses did not make the conditions more favorable for banks. Croatian banks have a rate of reserve requirement of $12 \%$, and the rate of total bank capital cannot be lower than $12 \%$, regardless of the Basel standard of $8 \%$.

The effectiveness of the monetary policy is best illustrated by the fact that during the financial and economic crisis $(2009$ - 2015) the monetary aggregate M1 was lower than M0, i.e., the monetary multiplier M1/M0 was less than 1.

The monetary authority undertook additional steps to alleviate the dramatic fall in GDP from 2009 to 2015 and private sector deleveraging by outright purchasing, increasing additional liquidity with the open market policy with reverse repo auctions, but only at the end of 2015. Consequently, there was an extreme liquidity excess that amounted to HRK 26 billion in 2017, with additional HRK 18 billion in foreign currency, accounting for $12 \%$ of GDP.

Excess liquidity is the difference between the balances on current accounts that commercial banks have with the Croatian Central Bank and the amount that the banks need to have on these accounts as a minimum reserve requirement. With such sterile liquidity of banks and the mediumterm stagnation of total loans to the private sector, there is still a positive shift: when we observe the system on the basis of loan transactions (charges/ payments), we can see that loans to citizens and businesses rose faster than GDP in 2017.

In addition, Croatia had been in the Excessive Deficit Procedure (EDP), an EU corrective mechanism, since January 2014, and left it at the proposal of the European Commission in May 2017. Croatia is continuing its convergence program.

As regards the unemployment issue, but also the closely related structure of employment (labor market structure), there are two important tendencies in the Republic of Croatia. One is related to the demographic decline and the other to a strong rise of emigration since its accession to the EU, which reduced the available workforce. On the one hand, this leads to pressures for higher salaries, and on the other, increases the potential need for imported labor force.

Salaries represent an element of expenditure that significantly affects the competitiveness of specific companies. However, salaries are also a key element of aggregate demand. Although in theory there is 
a common belief that a more "flexible" and "fluid" labor market ensures faster redistribution of work, the latest research (Dosi et al., 2017) shows that this could make the entire economic system more fragile and prone to recession. Therefore, there are suggestions based on workforce protection and productivity sharing according to (a) labor market regulations and (b) macroeconomic dynamics (long-term growth rates, GDP fluctuations, unemployment rates, inequity, etc.).

In these conditions, Croatia has to turn to the automatization of jobs and work places and to robotization, which will surely change the structure of the labor market, but also the taxation and pension system.

The excess liquidity of banks should turn, with government interventions and support, toward stimulating research and development and starting high-technology businesses that would in turn have to constantly invest in retraining and skills development of the existing workforce for high-technology processes and utilization of modern information technologies.

These steps could also lead to satisfactory financial development that would gradually shift its focus from the current position of basic monetization, i.e., mainly bank orientation, toward a more complex financial instruments market.

A further increase in the ratio of Loans/GDP to the levels of 70 to 74 that is required after a gradual decrease in unemployment to the desired rate of $5 \%$, and the need for the banking system to focus more on households once a satisfactory level of corporate environment has been achieved, should be directed not only toward consumption (which should naturally follow the increase in income due to the new occupational structure), but also toward investment of citizens in education and life-ling development.

\section{Conclusion}

A modern approach to measuring the monetary policy effects on economic growth and its indicators requires an indirect approach based on empirical research of mainly financial infrastructure, competitiveness of the financial markets and current economic conditions.

Based on the analysis of selected indicators M1/GDP, Loans/GDP and Gross debt/GDP and Unemployment rate using ANFIS, conducted on the data set for the period from 1995 to 2016, we can say that:

a) the rate of unemployment is conditioned by the financial cycle and the monetary policy (M1/
GDP, Loans/GDP), as well as the business cycle and the fiscal policy (gross $\mathrm{d} / \mathrm{BDP}$ ), and

b) a controlled and properly directed level of monetization of economy (M1/BDP) and the financial development measured by Loans/GDP can be deemed "sufficient" for economic growth.

Based on the above, it seemed justified to determine the best sizes of the indicators of monetization, financial development and public debt in relation to unemployment rate.

Thus, the set models analyzed through ANFIS show that the natural unemployment rate ranged from 8.5 to $10 \%$. This range of unemployment rate, the achieved levels of monetization, financial development and public debt trends facilitate further economic growth and objectively correspond to Croatian monetary and fiscal conditions.

At this moment, the money supply and the movement of monetary aggregates (M1 and M0) are a secondary objective of Croatian monetary policy, the nominal anchor of which is the fluctuating exchange rate. As long as the monetary strategy of the exchange rate as a nominal anchor implemented by the Croatian National Bank has the role of anticipating the ERM II regime, the fiscal adjustment through public debt and taxation management aimed at the rise of interest rates remains a weak point of the political agenda.

Nevertheless, it is clear that waiting in the "monetary union lobby", i.e., waiting for the ERM II exchange mechanism, can last longer than the set deadlines, leading to the need for Croatian economic policy to optimize monetary and fiscal policy measures in order to increase economic growth and reduce unemployment.

Therefore, this paper contributes to a better understanding of opportunities and limitations of economic policy with regard to unemployment rate trends, i.e., the natural unemployment rate, in both theoretical and applicative sense.

A theoretical contribution is in defining a modern approach to contemplating the effects of a monetary policy on economic growth and its indicators, while its empirical contribution is in using ANFIS in the modeling of the relationships between M1/ GDP, Loans/GDP and Gross debt/GDP ratios and unemployment.

Recommendations for further research are to conduct an in-depth analysis of the defined variables of financial infrastructure, competitiveness of financial markets and current economic conditions. 


\section{Appendix}

Table 3 Ratio M1/GDP and Loans/GDP not considering the set criteria for Gross debt/GDP and with criteria of Unemployment rate 5

\begin{tabular}{|c|c|c|c|c|c|c|c|}
\hline $\begin{array}{l}\text { M1/ } \\
\text { GDP }\end{array}$ & $\begin{array}{c}\text { Loans/ } \\
\text { GDP }\end{array}$ & $\begin{array}{c}\text { Gross debt/ } \\
\text { GDP }\end{array}$ & Unemployment & $\begin{array}{l}\text { M1/ } \\
\text { GDP }\end{array}$ & $\begin{array}{c}\text { Loans/ } \\
\text { GDP }\end{array}$ & $\begin{array}{c}\text { Gross debt/ } \\
\text { GDP }\end{array}$ & Unemployment \\
\hline 8.3 & 42.8 & 44.6 & 5.00 & 14.3 & 46.8 & 46.1 & 5.00 \\
\hline 8.3 & 45.8 & 44.1 & 5.00 & 14.3 & 47.3 & 25.1 & 5.00 \\
\hline 9.3 & 45.3 & 44.6 & 5.00 & 14.3 & 58.8 & 58.1 & 5.00 \\
\hline 9.8 & 32.3 & 46.1 & 5.00 & 15.3 & 43.3 & 25.6 & 5.00 \\
\hline 9.8 & 57.3 & 31.1 & 5.00 & 15.3 & 58.8 & 55.6 & 5.00 \\
\hline 9.8 & 57.8 & 36.1 & 5.00 & 15.3 & 64.3 & 27.1 & 5.00 \\
\hline 9.8 & 57.8 & 36.6 & 5.00 & 15.3 & 69.8 & 42.1 & 5.00 \\
\hline 10.3 & 73.3 & 47.6 & 5.00 & 15.8 & 35.3 & 37.6 & 5.00 \\
\hline 10.8 & 57.8 & 46.1 & 5.00 & 15.8 & 38.8 & 45.6 & 5.00 \\
\hline 10.8 & 61.8 & 51.6 & 5.00 & 15.8 & 57.8 & 82.6 & 5.00 \\
\hline 10.8 & 61.8 & 52.1 & 5.00 & 16.3 & 41.8 & 46.1 & 5.00 \\
\hline 10.8 & 61.8 & 52.6 & 5.00 & 16.8 & 47.3 & 45.6 & 5.00 \\
\hline 10.8 & 61.8 & 53.1 & 5.00 & 16.8 & 56.3 & 26.1 & 5.00 \\
\hline 10.8 & 64.3 & 48.6 & 5.00 & 16.8 & 58.8 & 49.6 & 5.00 \\
\hline 10.8 & 64.3 & 57.1 & 5.00 & 17.3 & 36.3 & 42.1 & 5.00 \\
\hline 10.8 & 74.8 & 59.6 & 5.00 & 17.3 & 44.8 & 26.1 & 5.00 \\
\hline 11.3 & 49.3 & 46.6 & 5.00 & 17.3 & 45.3 & 26.1 & 5.00 \\
\hline 11.3 & 60.8 & 48.6 & 5.00 & 17.3 & 45.8 & 26.1 & 5.00 \\
\hline 11.3 & 62.3 & 57.6 & 5.00 & 17.3 & 57.3 & 45.6 & 5.00 \\
\hline 11.3 & 65.3 & 47.1 & 5.00 & 17.3 & 58.8 & 57.6 & 5.00 \\
\hline 11.8 & 41.3 & 19.6 & 5.00 & 18.3 & 52.3 & 42.6 & 5.00 \\
\hline 11.8 & 47.3 & 22.6 & 5.00 & 18.3 & 61.3 & 49.6 & 5.00 \\
\hline 11.8 & 48.3 & 46.6 & 5.00 & 18.3 & 62.3 & 27.1 & 5.00 \\
\hline 11.8 & 55.3 & 25.6 & 5.00 & 18.3 & 63.3 & 27.1 & 5.00 \\
\hline 11.8 & 60.3 & 53.1 & 5.00 & 18.3 & 71.8 & 48.1 & 5.00 \\
\hline 11.8 & 65.8 & 46.6 & 5.00 & 18.3 & 74.8 & 49.1 & 5.00 \\
\hline 12.3 & 45.3 & 20.1 & 5.00 & 18.8 & 73.3 & 67.6 & 5.00 \\
\hline 12.3 & 60.8 & 46.1 & 5.00 & 19.3 & 73.8 & 72.6 & 5.00 \\
\hline 12.8 & 46.8 & 22.6 & 5.00 & 19.3 & 74.3 & 72.6 & 5.00 \\
\hline 12.8 & 61.3 & 59.1 & 5.00 & 19.8 & 63.8 & 44.6 & 5.00 \\
\hline 13.3 & 42.3 & 22.1 & 5.00 & 19.8 & 64.3 & 44.6 & 5.00 \\
\hline 13.3 & 47.3 & 23.6 & 5.00 & 20.3 & 67.3 & 74.1 & 5.00 \\
\hline 13.3 & 55.8 & 46.6 & 5.00 & 20.8 & 63.3 & 44.1 & 5.00 \\
\hline 13.3 & 58.3 & 47.1 & 5.00 & 20.8 & 69.3 & 42.1 & 5.00 \\
\hline
\end{tabular}

Source: Authors 
Table 4 Ratio M1/GDP and Loans/GDP not considering the set criteria for Gross debt/GDP and with criteria of Unemployment rate 7

\begin{tabular}{|c|c|c|c|c|c|c|c|}
\hline $\begin{array}{l}\text { M1/ } \\
\text { GDP }\end{array}$ & $\begin{array}{c}\text { Loans/ } \\
\text { GDP }\end{array}$ & $\begin{array}{c}\text { Gross debt/ } \\
\text { GDP }\end{array}$ & Unemployment & $\begin{array}{l}\text { M1/ } \\
\text { GDP }\end{array}$ & $\begin{array}{c}\text { Loans/ } \\
\text { GDP }\end{array}$ & $\begin{array}{c}\text { Gross debt/ } \\
\text { GDP }\end{array}$ & Unemployment \\
\hline 8.3 & 48.3 & 23.6 & 7.00 & 14.3 & 55.8 & 27.1 & 7.00 \\
\hline 8.8 & 47.8 & 35.1 & 7.00 & 14.3 & 58.8 & 74.6 & 7.00 \\
\hline 8.8 & 48.3 & 20.1 & 7.00 & 14.3 & 59.3 & 60.6 & 7.00 \\
\hline 9.3 & 48.3 & 28.6 & 7.00 & 14.8 & 59.8 & 48.6 & 7.00 \\
\hline 9.8 & 53.3 & 34.1 & 7.00 & 14.8 & 67.3 & 33.6 & 7.00 \\
\hline 9.8 & 53.3 & 37.6 & 7.00 & 15.3 & 53.8 & 27.1 & 7.00 \\
\hline 10.3 & 50.3 & 27.1 & 7.00 & 15.3 & 58.8 & 27.6 & 7.00 \\
\hline 10.8 & 37.3 & 45.1 & 7.00 & 15.3 & 59.3 & 46.6 & 7.00 \\
\hline 10.8 & 38.8 & 25.1 & 7.00 & 15.8 & 36.3 & 34.1 & 7.00 \\
\hline 11.3 & 54.3 & 45.1 & 7.00 & 15.8 & 51.8 & 27.1 & 7.00 \\
\hline 11.3 & 72.3 & 50.1 & 7.00 & 15.8 & 59.8 & 53.6 & 7.00 \\
\hline 11.3 & 75.3 & 48.6 & 7.00 & 15.8 & 65.8 & 29.1 & 7.00 \\
\hline 11.8 & 33.3 & 27.6 & 7.00 & 16.3 & 50.3 & 44.1 & 7.00 \\
\hline 11.8 & 39.3 & 45.1 & 7.00 & 16.3 & 72.3 & 45.6 & 7.00 \\
\hline 11.8 & 58.8 & 30.1 & 7.00 & 16.8 & 44.3 & 27.1 & 7.00 \\
\hline 11.8 & 71.3 & 55.6 & 7.00 & 16.8 & 46.3 & 27.1 & 7.00 \\
\hline 11.8 & 73.8 & 57.1 & 7.00 & 16.8 & 55.8 & 44.1 & 7.00 \\
\hline 12.3 & 40.8 & 25.1 & 7.00 & 17.3 & 47.8 & 44.1 & 7.00 \\
\hline 12.3 & 45.3 & 45.1 & 7.00 & 17.8 & 37.3 & 36.1 & 7.00 \\
\hline 12.3 & 53.3 & 26.6 & 7.00 & 17.8 & 37.3 & 36.6 & 7.00 \\
\hline 12.3 & 70.8 & 56.1 & 7.00 & 17.8 & 38.3 & 42.1 & 7.00 \\
\hline 12.3 & 74.3 & 47.6 & 7.00 & 17.8 & 45.3 & 43.6 & 7.00 \\
\hline 12.8 & 34.8 & 27.6 & 7.00 & 17.8 & 54.8 & 43.1 & 7.00 \\
\hline 12.8 & 37.3 & 45.1 & 7.00 & 17.8 & 64.3 & 28.6 & 7.00 \\
\hline 12.8 & 45.3 & 45.1 & 7.00 & 18.3 & 54.3 & 37.1 & 7.00 \\
\hline 12.8 & 53.3 & 26.6 & 7.00 & 18.3 & 56.8 & 40.1 & 7.00 \\
\hline 12.8 & 69.3 & 52.1 & 7.00 & 18.3 & 62.3 & 60.1 & 7.00 \\
\hline 13.3 & 46.8 & 45.1 & 7.00 & 18.3 & 63.3 & 45.1 & 7.00 \\
\hline 13.3 & 52.8 & 26.6 & 7.00 & 18.3 & 65.3 & 45.1 & 7.00 \\
\hline 13.3 & 53.8 & 45.1 & 7.00 & 18.8 & 59.3 & 32.6 & 7.00 \\
\hline 13.3 & 67.3 & 56.6 & 7.00 & 18.8 & 60.8 & 29.6 & 7.00 \\
\hline 13.3 & 67.8 & 50.6 & 7.00 & 18.8 & 68.3 & 72.6 & 7.00 \\
\hline 13.3 & 68.3 & 57.6 & 7.00 & 18.8 & 69.8 & 73.1 & 7.00 \\
\hline 13.8 & 37.3 & 44.6 & 7.00 & 19.3 & 59.8 & 32.6 & 7.00 \\
\hline 13.8 & 50.8 & 26.6 & 7.00 & 19.3 & 66.3 & 75.1 & 7.00 \\
\hline 13.8 & 61.3 & 56.6 & 7.00 & 19.3 & 68.8 & 38.6 & 7.00 \\
\hline 13.8 & 64.3 & 46.6 & 7.00 & 19.8 & 65.8 & 42.6 & 7.00 \\
\hline 13.8 & 68.3 & 79.1 & 7.00 & 19.8 & 67.8 & 41.6 & 7.00 \\
\hline 13.8 & 68.8 & 79.1 & 7.00 & 19.8 & 68.8 & 34.6 & 7.00 \\
\hline 13.8 & 70.8 & 79.6 & 7.00 & 19.8 & 68.8 & 38.1 & 7.00 \\
\hline 13.8 & 70.8 & 80.1 & 7.00 & 20.3 & 58.8 & 80.6 & 7.00 \\
\hline 13.8 & 71.3 & 78.6 & 7.00 & 21.3 & 66.3 & 40.1 & 7.00 \\
\hline 13.8 & 71.8 & 64.1 & 7.00 & 21.3 & 67.3 & 38.1 & 7.00 \\
\hline 14.3 & 31.8 & 37.1 & 7.00 & 22.3 & 58.3 & 83.1 & 7.00 \\
\hline 14.3 & 32.3 & 38.6 & 7.00 & 22.3 & 62.3 & 76.6 & 7.00 \\
\hline
\end{tabular}

Source: Authors 
Table 5 Ratio M1/GDP and Loans/GDP not considering the set criteria for Gross debt/GDP and with criteria of Unemployment rate 8.5

\begin{tabular}{|c|c|c|c|c|c|c|c|}
\hline $\begin{array}{l}\text { M1/ } \\
\text { GDP }\end{array}$ & $\begin{array}{c}\text { Loans/ } \\
\text { GDP }\end{array}$ & $\begin{array}{c}\text { Gross debt/ } \\
\text { GDP }\end{array}$ & Unemployment & $\begin{array}{l}\text { M1/ } \\
\text { GDP }\end{array}$ & $\begin{array}{c}\text { Loans/ } \\
\text { GDP }\end{array}$ & $\begin{array}{c}\text { Gross debt/ } \\
\text { GDP }\end{array}$ & Unemployment \\
\hline 8.3 & 38.8 & 42.6 & 8.50 & 15.3 & 59.3 & 84.1 & 8.50 \\
\hline 8.3 & 41.8 & 42.1 & 8.50 & 15.3 & 66.8 & 36.6 & 8.50 \\
\hline 8.3 & 47.8 & 19.1 & 8.50 & 15.8 & 66.8 & 34.1 & 8.50 \\
\hline 8.8 & 39.3 & 42.6 & 8.50 & 16.3 & 38.3 & 29.1 & 8.50 \\
\hline 8.8 & 46.8 & 36.6 & 8.50 & 16.3 & 54.8 & 28.1 & 8.50 \\
\hline 9.8 & 34.3 & 44.1 & 8.50 & 16.3 & 59.3 & 44.6 & 8.50 \\
\hline 9.8 & 37.3 & 20.1 & 8.50 & 16.3 & 65.3 & 30.6 & 8.50 \\
\hline 9.8 & 49.3 & 33.1 & 8.50 & 16.8 & 37.3 & 32.1 & 8.50 \\
\hline 10.3 & 42.8 & 23.6 & 8.50 & 16.8 & 39.3 & 28.6 & 8.50 \\
\hline 10.3 & 51.8 & 43.1 & 8.50 & 16.8 & 69.8 & 45.6 & 8.50 \\
\hline 10.3 & 52.3 & 28.6 & 8.50 & 16.8 & 73.8 & 47.1 & 8.50 \\
\hline 10.8 & 31.8 & 44.6 & 8.50 & 17.3 & 48.8 & 43.1 & 8.50 \\
\hline 10.8 & 43.3 & 25.6 & 8.50 & 17.3 & 56.3 & 28.6 & 8.50 \\
\hline 10.8 & 51.3 & 44.1 & 8.50 & 17.8 & 65.8 & 53.6 & 8.50 \\
\hline 11.3 & 33.8 & 44.6 & 8.50 & 17.8 & 66.3 & 53.1 & 8.50 \\
\hline 11.8 & 32.3 & 44.6 & 8.50 & 17.8 & 66.8 & 45.6 & 8.50 \\
\hline 11.8 & 57.3 & 43.6 & 8.50 & 17.8 & 67.3 & 36.1 & 8.50 \\
\hline 12.3 & 49.8 & 27.1 & 8.50 & 17.8 & 67.8 & 52.1 & 8.50 \\
\hline 12.3 & 58.8 & 35.1 & 8.50 & 17.8 & 69.3 & 51.6 & 8.50 \\
\hline 12.3 & 58.8 & 38.6 & 8.50 & 17.8 & 69.8 & 51.6 & 8.50 \\
\hline 12.8 & 58.3 & 42.6 & 8.50 & 18.3 & 59.8 & 41.1 & 8.50 \\
\hline 13.3 & 35.3 & 44.1 & 8.50 & 18.3 & 59.8 & 76.1 & 8.50 \\
\hline 13.8 & 36.3 & 28.6 & 8.50 & 18.3 & 64.3 & 30.6 & 8.50 \\
\hline 13.8 & 53.8 & 27.6 & 8.50 & 18.3 & 67.3 & 36.1 & 8.50 \\
\hline 13.8 & 63.3 & 64.1 & 8.50 & 18.3 & 72.8 & 69.6 & 8.50 \\
\hline 13.8 & 64.3 & 72.6 & 8.50 & 18.8 & 62.8 & 75.6 & 8.50 \\
\hline 13.8 & 66.8 & 72.6 & 8.50 & 18.8 & 65.8 & 41.1 & 8.50 \\
\hline 13.8 & 67.3 & 71.6 & 8.50 & 18.8 & 67.3 & 36.1 & 8.50 \\
\hline 13.8 & 67.8 & 62.6 & 8.50 & 19.3 & 62.3 & 40.6 & 8.50 \\
\hline 13.8 & 67.8 & 68.6 & 8.50 & 19.3 & 65.3 & 31.6 & 8.50 \\
\hline 13.8 & 70.3 & 59.1 & 8.50 & 19.3 & 66.3 & 40.1 & 8.50 \\
\hline 14.3 & 61.3 & 41.1 & 8.50 & 19.8 & 61.8 & 33.1 & 8.50 \\
\hline 14.3 & 67.3 & 46.1 & 8.50 & 20.3 & 61.8 & 35.6 & 8.50 \\
\hline 14.8 & 42.3 & 27.6 & 8.50 & 20.3 & 61.8 & 36.6 & 8.50 \\
\hline 14.8 & 50.3 & 43.6 & 8.50 & 20.3 & 65.8 & 39.1 & 8.50 \\
\hline 14.8 & 60.3 & 29.6 & 8.50 & 20.3 & 66.3 & 34.1 & 8.50 \\
\hline 14.8 & 66.3 & 40.6 & 8.50 & 20.8 & 63.3 & 36.1 & 8.50 \\
\hline 15.3 & 36.8 & 38.6 & 8.50 & 20.8 & 63.3 & 36.6 & 8.50 \\
\hline 15.3 & 43.8 & 44.1 & 8.50 & 20.8 & 64.8 & 35.6 & 8.50 \\
\hline 15.3 & 58.8 & 77.6 & 8.50 & 21.8 & 71.8 & 78.1 & 8.50 \\
\hline
\end{tabular}

Source: Authors 
Table 6 Ratio M1/GDP and Loans/GDP not considering the set criteria for Gross debt/GDP and with criteria of Unemployment rate 9

\begin{tabular}{|c|c|c|c|c|c|c|c|}
\hline $\begin{array}{l}\text { M1/ } \\
\text { GDP }\end{array}$ & $\begin{array}{c}\text { Loans/ } \\
\text { GDP }\end{array}$ & $\begin{array}{c}\text { Gross debt/ } \\
\text { GDP }\end{array}$ & Unemployment & $\begin{array}{l}\text { M1/ } \\
\text { GDP }\end{array}$ & $\begin{array}{c}\text { Loans/ } \\
\text { GDP }\end{array}$ & $\begin{array}{c}\text { Gross debt/ } \\
\text { GDP }\end{array}$ & Unemployment \\
\hline 8.8 & 47.3 & 26.6 & 9.00 & 14.8 & 64.8 & 37.6 & 9.00 \\
\hline 9.3 & 33.3 & 23.6 & 9.00 & 15.3 & 49.8 & 28.1 & 9.00 \\
\hline 9.3 & 47.3 & 25.1 & 9.00 & 15.3 & 66.8 & 41.6 & 9.00 \\
\hline 9.8 & 48.3 & 39.6 & 9.00 & 15.8 & 61.3 & 49.6 & 9.00 \\
\hline 9.8 & 48.8 & 33.6 & 9.00 & 15.8 & 61.3 & 50.1 & 9.00 \\
\hline 10.3 & 52.8 & 29.1 & 9.00 & 15.8 & 61.3 & 50.6 & 9.00 \\
\hline 10.8 & 42.8 & 26.1 & 9.00 & 15.8 & 66.8 & 39.1 & 9.00 \\
\hline 10.8 & 55.8 & 28.6 & 9.00 & 16.3 & 57.3 & 28.6 & 9.00 \\
\hline 11.3 & 49.3 & 44.1 & 9.00 & 16.3 & 61.3 & 52.1 & 9.00 \\
\hline 11.3 & 51.3 & 27.6 & 9.00 & 16.8 & 37.3 & 36.1 & 9.00 \\
\hline 11.3 & 51.3 & 44.1 & 9.00 & 16.8 & 37.3 & 36.6 & 9.00 \\
\hline 11.8 & 35.3 & 28.1 & 9.00 & 16.8 & 38.8 & 42.6 & 9.00 \\
\hline 11.8 & 45.8 & 26.6 & 9.00 & 16.8 & 40.3 & 28.6 & 9.00 \\
\hline 11.8 & 52.3 & 27.6 & 9.00 & 16.8 & 59.8 & 59.6 & 9.00 \\
\hline 11.8 & 56.8 & 28.6 & 9.00 & 17.3 & 47.3 & 28.6 & 9.00 \\
\hline 12.3 & 37.3 & 27.6 & 9.00 & 17.3 & 51.3 & 42.6 & 9.00 \\
\hline 12.3 & 58.3 & 31.1 & 9.00 & 17.3 & 58.8 & 64.6 & 9.00 \\
\hline 13.3 & 48.3 & 44.1 & 9.00 & 17.3 & 68.8 & 46.1 & 9.00 \\
\hline 13.3 & 51.8 & 44.1 & 9.00 & 17.8 & 63.3 & 30.6 & 9.00 \\
\hline 13.8 & 34.8 & 29.6 & 9.00 & 17.8 & 63.3 & 44.6 & 9.00 \\
\hline 13.8 & 56.3 & 43.6 & 9.00 & 17.8 & 64.3 & 44.6 & 9.00 \\
\hline 13.8 & 74.3 & 51.1 & 9.00 & 17.8 & 66.8 & 37.1 & 9.00 \\
\hline 14.3 & 58.8 & 43.1 & 9.00 & 17.8 & 72.3 & 54.6 & 9.00 \\
\hline 14.3 & 60.3 & 60.6 & 9.00 & 18.3 & 60.3 & 32.6 & 9.00 \\
\hline 14.3 & 65.3 & 49.1 & 9.00 & 18.3 & 61.3 & 65.6 & 9.00 \\
\hline 14.3 & 65.8 & 48.6 & 9.00 & 18.3 & 64.3 & 31.6 & 9.00 \\
\hline 14.3 & 67.3 & 48.1 & 9.00 & 18.3 & 66.3 & 40.1 & 9.00 \\
\hline 14.3 & 69.3 & 48.1 & 9.00 & 18.8 & 61.3 & 34.6 & 9.00 \\
\hline 14.8 & 52.3 & 28.1 & 9.00 & 18.8 & 62.8 & 76.1 & 9.00 \\
\hline 14.8 & 59.8 & 84.1 & 9.00 & 19.3 & 66.3 & 76.6 & 9.00 \\
\hline 14.8 & 60.8 & 30.6 & 9.00 & 19.8 & 62.8 & 34.6 & 9.00 \\
\hline 14.8 & 60.8 & 57.1 & 9.00 & 19.8 & 64.8 & 34.1 & 9.00 \\
\hline
\end{tabular}

Source: Authors 
Table 7 Ratio M1/GDP and Loans/GDP not considering the set criteria for Gross debt/GDP and with criteria of Unemployment rate 9

\begin{tabular}{|c|c|c|c|c|c|c|c|}
\hline $\begin{array}{l}\text { M1/ } \\
\text { GDP }\end{array}$ & $\begin{array}{c}\text { Loans/ } \\
\text { GDP }\end{array}$ & $\begin{array}{c}\text { Gross debt/ } \\
\text { GDP }\end{array}$ & Unemployment & $\begin{array}{l}\text { M1/ } \\
\text { GDP }\end{array}$ & $\begin{array}{c}\text { Loans/ } \\
\text { GDP }\end{array}$ & $\begin{array}{c}\text { Gross debt/ } \\
\text { GDP }\end{array}$ & Unemployment \\
\hline 8.3 & 31.8 & 21.1 & 10.00 & 14.8 & 68.3 & 48.6 & 10.00 \\
\hline 8.8 & 46.8 & 26.6 & 10.00 & 15.3 & 56.8 & 29.1 & 10.00 \\
\hline 9.3 & 33.3 & 25.6 & 10.00 & 15.3 & 60.8 & 43.6 & 10.00 \\
\hline 9.3 & 39.3 & 41.6 & 10.00 & 15.3 & 62.3 & 44.6 & 10.00 \\
\hline 9.8 & 38.3 & 42.6 & 10.00 & 15.3 & 62.3 & 54.6 & 10.00 \\
\hline 9.8 & 45.8 & 24.1 & 10.00 & 15.3 & 62.8 & 45.1 & 10.00 \\
\hline 9.8 & 47.3 & 39.6 & 10.00 & 15.3 & 66.3 & 45.6 & 10.00 \\
\hline 9.8 & 47.8 & 32.1 & 10.00 & 15.3 & 72.8 & 48.6 & 10.00 \\
\hline 9.8 & 47.8 & 37.1 & 10.00 & 15.8 & 51.3 & 42.6 & 10.00 \\
\hline 10.3 & 50.8 & 29.6 & 10.00 & 15.8 & 65.3 & 40.1 & 10.00 \\
\hline 10.8 & 57.8 & 38.6 & 10.00 & 15.8 & 66.3 & 44.6 & 10.00 \\
\hline 11.3 & 32.8 & 28.6 & 10.00 & 15.8 & 73.8 & 48.6 & 10.00 \\
\hline 11.3 & 36.8 & 28.1 & 10.00 & 16.3 & 37.8 & 32.6 & 10.00 \\
\hline 11.3 & 54.8 & 28.6 & 10.00 & 16.3 & 46.3 & 43.1 & 10.00 \\
\hline 12.3 & 46.3 & 43.6 & 10.00 & 16.3 & 62.8 & 46.1 & 10.00 \\
\hline 12.3 & 57.8 & 41.6 & 10.00 & 16.3 & 64.3 & 33.6 & 10.00 \\
\hline 12.8 & 38.8 & 43.6 & 10.00 & 16.3 & 69.3 & 47.6 & 10.00 \\
\hline 12.8 & 46.3 & 43.6 & 10.00 & 16.8 & 51.3 & 29.1 & 10.00 \\
\hline 12.8 & 58.3 & 34.1 & 10.00 & 16.8 & 58.8 & 68.6 & 10.00 \\
\hline 13.3 & 46.8 & 27.6 & 10.00 & 16.8 & 58.8 & 71.1 & 10.00 \\
\hline 13.3 & 51.8 & 43.6 & 10.00 & 16.8 & 59.3 & 62.1 & 10.00 \\
\hline 13.8 & 49.3 & 28.1 & 10.00 & 16.8 & 64.3 & 47.6 & 10.00 \\
\hline 14.3 & 36.3 & 38.1 & 10.00 & 16.8 & 64.3 & 48.1 & 10.00 \\
\hline 14.3 & 37.8 & 29.6 & 10.00 & 16.8 & 64.3 & 48.6 & 10.00 \\
\hline 14.3 & 59.3 & 32.6 & 10.00 & 16.8 & 64.3 & 49.1 & 10.00 \\
\hline 14.3 & 59.8 & 70.6 & 10.00 & 16.8 & 65.8 & 42.6 & 10.00 \\
\hline 14.3 & 60.8 & 78.1 & 10.00 & 16.8 & 68.3 & 47.6 & 10.00 \\
\hline 14.3 & 68.3 & 55.6 & 10.00 & 17.3 & 51.8 & 29.6 & 10.00 \\
\hline 14.3 & 68.8 & 55.1 & 10.00 & 17.3 & 62.8 & 44.1 & 10.00 \\
\hline 14.8 & 59.3 & 42.6 & 10.00 & 17.3 & 64.8 & 34.6 & 10.00 \\
\hline 14.8 & 59.8 & 79.1 & 10.00 & 17.3 & 65.3 & 42.6 & 10.00 \\
\hline 14.8 & 60.8 & 33.1 & 10.00 & 17.3 & 66.8 & 52.6 & 10.00 \\
\hline 14.8 & 61.8 & 36.6 & 10.00 & 17.3 & 70.3 & 51.1 & 10.00 \\
\hline 14.8 & 61.8 & 41.1 & 10.00 & 17.8 & 50.3 & 32.1 & 10.00 \\
\hline 14.8 & 61.8 & 57.1 & 10.00 & 17.8 & 63.3 & 33.1 & 10.00 \\
\hline 14.8 & 63.8 & 53.1 & 10.00 & 17.8 & 63.8 & 33.6 & 10.00 \\
\hline 14.8 & 65.3 & 50.1 & 10.00 & 18.3 & 61.3 & 73.6 & 10.00 \\
\hline 14.8 & 67.3 & 48.6 & 10.00 & 18.3 & 68.8 & 67.6 & 10.00 \\
\hline 14.8 & 67.8 & 48.6 & 10.00 & 21.3 & 60.8 & 79.1 & 10.00 \\
\hline
\end{tabular}

Source: Authors 


\section{REFERENCES}

1. Abdel-Aleem, A., El-Sharief, A. M., Hassan, A. M. \& El-Sebaie, G. M. (2017). Implementation of Fuzzy and Adaptive Neuro-Fuzzy Inference Systems in Optimization of Production Inventory Problem. Applied Mathematics E Information Sciences, 11(1), 289-298. https://doi.org/10.18576/amis/110135

2. Aghion, P. \& Howitt, P. (1994). Growth and unemployment. The Review of Economic Studies, 61(3), 477-494. https://doi.org/10.2307/2297900

3. Andabaka, A., Družić, I. \& Mustać, N. (2017). Pokretači javnoga duga u Hrvatskoj. Ekonomski Pregled, 68(5), 463-487.

4. Ambukege, G., Justo, G. \& Mushi, J. (2017). Neuro fuzzy modelling for prediction of consumer price index. International Journal of Artificial Intelligence and Applications, 8(5), 33-44. https://doi.org/10.5121/ijaia.2017.8503

5. Ankargren, S., Bjellerup, M. \& Shahnazarian, H. (2017). The importance of the financial system for the real economy. Empirical Economics, 53(4), 1553-1586. https://doi.org/10.1007/s00181-016-1175-4

6. Autor, D. \& Dorn, D. (2013). The growth of low skill service jobs and the polarization of the US labor market. American Economic Review, 103(5), 1553-1597. https://doi.org/10.1257/aer.103.5.1553

7. Avci, B. S. \& Yucel, E. (2017). Effectiveness of monetary policy: evidence from Turkey. Eurasian Economic Review, 7(2), 179-213. https://doi.org/10.1007/s40822-017-0068-y

8. Azizi, A., Bin, A. A. Y. \& Ping, L. W. (2015). Modelling production uncertainties using the adaptive neuro-fuzzy inference system. South African Journal of Industrial Engineering, 26(1), 224-234. https://doi.org/10.7166/26-1-560

9. Benazić, M. \& Rami, J. (2016). Monetary policy and unemployment in Croatia. Ekonomska istraživanja, 29(1), 1038-1049. https://doi.org/10.1080/1331677X.2016.1211955

10. Bošnjak, M., Bilas, V. \& Franc, S. (2017). Long memory property of (un)employment in Croatia. In Tomé, E. et al. (Eds.). Proceedings of the International Conference Theory and Applications in the Knowledge Economy (pp. 727-737). Zagreb: Faculty of Economics and E4 Conferences.

11. Capolupo, R. (2017). Finance, Investment and Growth: Evidence for Italy. Economic Notes: Review of Banking, Finance and Monetary Economics, 47(1), 145-186. https://doi.org/10.1111/ecno.12097

12. Cheng, K. J. G. \& Daway, S. L. S. (2017). The role of domestic financial and economic development in financial integration. Applied Economics Letters, 25(2), 119-124. https://doi.org/10.1080/13504851.2017.1302054

13. Desbordes, R. \& Wei, S. J. (2017). The effects of financial development on foreign direct investment. Journal of Development Economics, 127(C), 153-168. https://doi.org/10.1016/j.jdeveco.2017.02.008

14. Deskar-Škrbić, M. \& Raos, V. (2017). Character of Fiscal Policy and Political Economy of Fiscal Consolidation in Croatia in the Post-Crisis Period. EFZG Working Paper Series, 13(2), 1-23.

15. Dosi, G., Pereira, M. C., Roventini, A. \& Virgillito, M. E. (2017). When more flexibility yields more fragility: The microfoundations of Keynesian aggregate unemployment. Journal of Economic Dynamics and Control, 81, 162-186. https://doi.org/10.1016/j.jedc.2017.02.005

16. Dumičić, M., Ljubaj, I. \& Martinis, A. (2017). Persistence of Euroisation in Croatia. Surveys S-31. Croatian National Bank.

17. Efendigil, T. (2014). Modelling product returns in a closed-loop supply chain under uncertainties: A neuro fuzzy approach. Journal of multiple-valued logic and soft computing, 23, 407-426.

18. Ellison, M. \& Sargent, T. J. (2015). Welfare cost of business cycles with idiosyncratic consumption risk and a preference for robustness. American Economic Journal: Macroeconomics, 7(2), 40-56. https://doi.org/10.1257/mac.20130098

19. Hall, R. E. (2011). The High Sensitivity of Economic Activity to Financial Frictions. Economic Journal, 121(552), 351-378. https://doi.org/10.1111/j.1468-0297.2011.02421.x 
20. Hall, R. E. (2013). Financial Frictions. International Journal of Central Banking, 9(2), 155-163.

21. Hartwell, C. A. (2018). Foreign banks and the business environment in transition: a cointegration approach. Post-Communist Economies, 30(1), 19-35. https://doi.org/10.1080/14631377.2017.1361703

22. Harvey, D. I., Kellard, N. M., Madsen, J. B. \& Wohard, M. E. (2017). Long-Run Commodity Prices Economic Growth, and Interest Rates: 17th Century to the Present Day. World Development, 89, 57-70. https://doi.org/10.1016/j.worlddev.2016.07.012

23. Hou, H. \& Cheng, S. Y. (2017). The dynamic effects of banking, life insurance, and stock markets on economic growth. Japan and the World Economy, 41, 87-98. https://doi.org/10.1016/j.japwor.2017.02.001

24. Jang, J. S. R. (1993). ANFIS: Adaptive-Network-based Fuzzy Inference Systems. IEEE Transactions on Systems, Man, and Cybernetics, 23(3), 665-685. https://doi.org/10.1109/21.256541

25. Jehan, Z. \& Hamid, A. (2017). Exchange rate volatility and capital inflows: role of financial development. Portuguese Economic Journal, 16(3), 189-203. https://doi.org/10.1007/s10258-017-0136-y

26. Kutan, A. M., Samargandi, N. \& Sohag, K. (2017). Does Institutional Quality Matter for Financial Development and Growth? Further Evidence from MENA Countries. Australian Economic Papers, 56(3), 228-248. https://doi.org/10.1111/1467-8454.12097

27. Lynch, D. (1996). Measuring Financial Sector Development: A Study Of Selected Asia-Pacific Countries. Developing Economies, 34(1), 3-33. https://doi.org/10.1111/j.1746-1049.1996.tb00727.x

28. Nyasha, S. \& Odhiambo, N. M. (2018). Financial Development and Economic Growth Nexus: A Revisionist Approach. Economic Notes: Review of Banking, Finance and Monetary Economics, 47(1), 223229. https://doi.org/10.1111/ecno.12101

29. Pera, J. (2016). Evaluation Of The Macroeconomic Stability Of Central And Eastern European Countries With A View Toward Their Membership In The European Union. Multidimensional Risk Analysis. Comparative Economic Research, 19(3), 69-92. https://doi.org/10.1515/cer-2016-0021

30. Pinheiro, T., Rivadeneyra, F. \& Teignier, M. (2017). Financial Development, Credit, and Business Cycles. Journal of Money, Credit and Banking, 49(7), 1653-1665. https://doi.org/10.1111/jmcb.12427

31. Prochniak, M. \& Wasiak, K. (2017). The impact of the financial system on economic growth in the context of the global crisis: empirical evidence for the EU and OECD countries. Empirica, 44(2), 295-337. https://doi.org/10.1007/s10663-016-9323-9

32. Rousseau, P. L. \& D'Onofrio, A. (2013). Monetization, Financial Development, and Growth: Time Series Evidence from 22 Countries in Sub-Saharan Africa. World Development, 51, 132-153.

https://doi.org/10.1016/j.worlddev.2013.05.016

33. Samodol, A. \& Brlečić Valčić, S. (2018). Spillover Effects Between Monetization, Financial Development And Public Debt In Relation With Unemployment In Croatia. In Omazic, M. A. et al. (Eds.). Proceedings of the 28th International Scientific Conference on Economic and Social Development (pp. 163-172). Paris: Faculty of Management University of Warsaw; University North.

34. Simionescu, M., Popescu, J. \& Firescu, V. (2017). The relationship between gross domestic product and monetary variables in Romania. A Bayesian approach. Ekonomska istraživanja, 30(1), 464-476. https://doi.org/10.1080/1331677X.2017.1305798

35. Sugeno, M. (1985). Industrial Applications of Fuzzy Control. Elsevier Science, Inc.

36. Valčić, M., Antonić, R. \& Tomas, V. (2011). ANFIS Based Model for Ship Speed Prediction. Brodogradnja, 62(4), 373-382. 